\title{
Can Another Great Volcanic Eruption Happen in Alaska?
}

he largest eruption on Earth
this century occurred at
Novarupta Volcano, Alaska, in
June 1912, creating Katmai
Caldera and the Valley of Ten
Thousand Smokes. Volcanic
ash (more than from all other
historical eruptions in Alaska
combined) devastated areas
hundreds of miles away. Such
massive eruptions will occur
again in southern Alaska,
threatening its rapidly grow-
ing population. To protect the
public, U.S. Geological Survey
(USGS) and other scientists with
the Alaska Volcano Observatory
closely monitor the State's many
active volcanoes.

On the afternoon of June 6,1912, an ominous cloud rose into the sky above Mount Katmai on the Alaska Peninsula. The cloud quickly reached an altitude of 20 miles, and within 4 hours, ash from a huge volcanic eruption began to fall on the village of Kodiak, 100 miles to the southeast. By the end of the eruption on June 9th, the ash cloud, now thousands of miles across, shrouded southern Alaska and western Canada, and sulfurous ash was falling on Vancouver, British Columbia, and Seattle, Washington. The next day the cloud passed over Virginia, and by June 17th it reached Algeria in Africa.

During the 3 days of the eruption, darkness and suffocating conditions caused by falling ash and sulfur dioxide gas immobilized the population of Kodiak. Sore eyes and respiratory distress were rampant, and water became undrinkable. Radio communications were totally disrupted, and with visibility near zero, ships couldn't dock. Roofs in Kodiak collapsed under the weight of more than a foot of ash, buildings were wrecked by ash avalanches that rushed down from nearby hillslopes, and other structures burned after being struck by lightning from the ash cloud.

Similar conditions prevailed elsewhere in southern Alaska, and several villages were abandoned forever. Animal and plant life was decimated by ash and acid rain from the eruption. Bears and other large animals were blinded by ash and starved when large

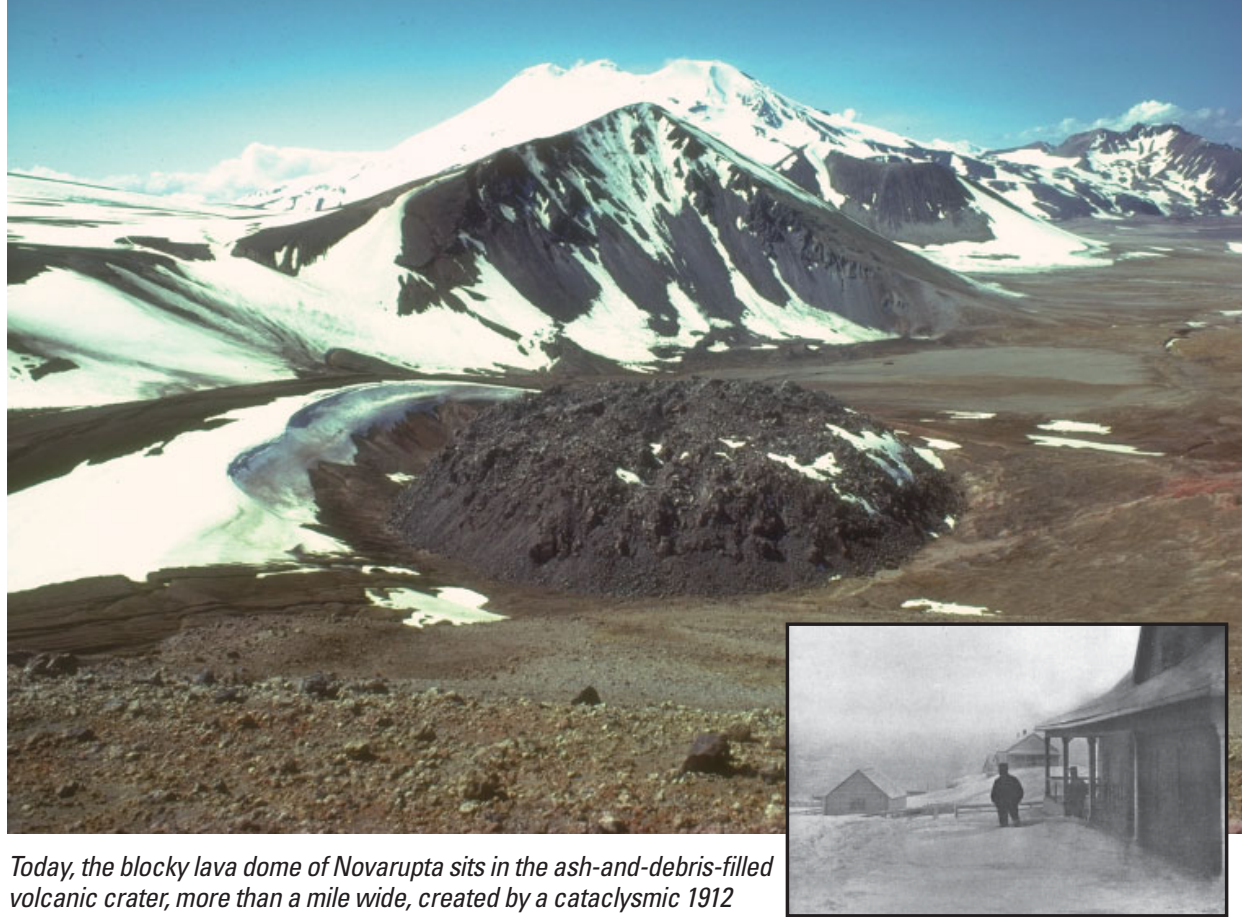
volcanic crater, more than a mile wide, created by a cataclysmic 1912 volcanic eruption that rained ash over southern Alaska, western Canada, and the Pacific Northwest. Snow-capped Mount Mageik, another potentially explosive volcano in Katmai National Park, can be seen in the background. Inset shows a resident of the devastated village of Kodiak, 100 miles southeast of Novarupta, standing in deep drifts of ash shortly after the June 1912 eruption (courtesy National Geographic Society).

numbers of the plants and small animals they lived on were wiped out. Millions of dead birds that had been blinded and coated by volcanic ash littered the ground. Aquatic organisms, such as mussels, insect larvae, and kelp, as well as the fish that fed upon them, perished in ash-choked shallow water. Alaska's salmon-fishing industry was devastated, especially from 1915 to 1919 , because of the starvation and failure of many adult fish to spawn in ash-choked streams.

In 1916, a National Geographic Society expedition led by Robert Griggs visited Mount Katmai and found a 2-mile-wide crater where its summit had been before 1912. Nearby, the

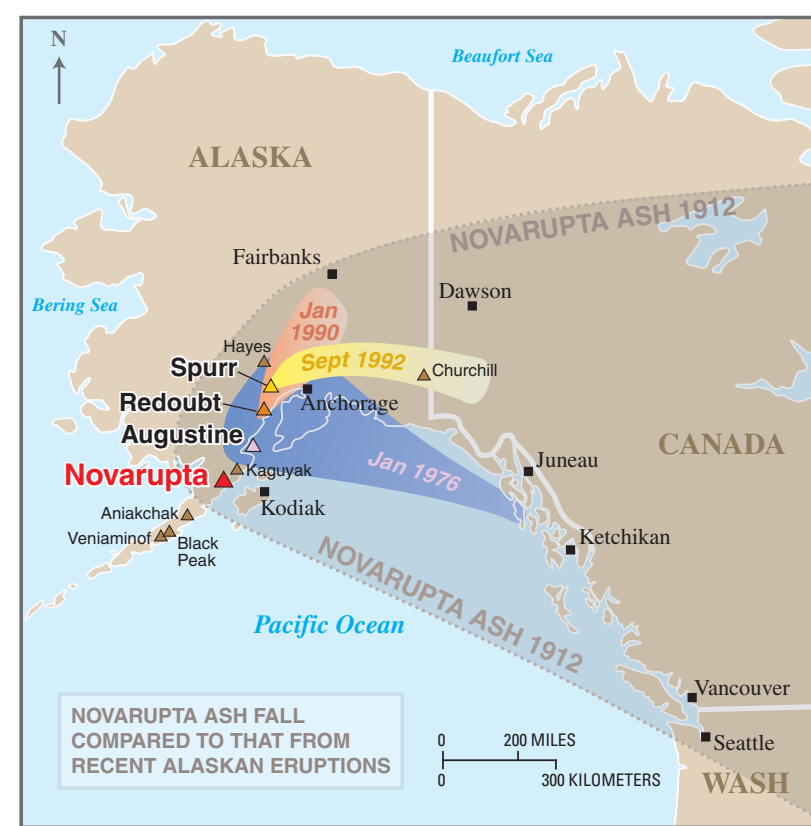

The ash fall from the cataclysmic 1912 eruption of Novarupta dwarfs that produced by recent eruptions of Augustine, Redoubt, and Spurr Volcanoes. Old-timers in Alaska can recall dozens of eruptions from these and other Alaskan volcanoes. Within 500 miles of Anchorage, several volcanoes (brown triangles) have exploded in Novarupta-scale eruptions in the past 4,000 years. Beyond the areas shown here, ash fall from these recent eruptions of Augustine, Redoubt, and Spurr Volcanoes was negligible, but ultrafine dust and sulfurous aerosols were held aloft and transported farther by high-altitude winds. Even though relatively small, the volcanic ash clouds from these eruptions still resulted in airport closures and damage to many jet aircraft. Because of the size and frequency of eruptions and prevailing winds, Alaskan volcanoes present a greater threat to aviation on the west coast of the United States than do the volcanoes of the Cascade Range in the Pacific Northwest. 
In the 1950's, volcanologists discovered that the great Alaskan eruption of 1912 was not from Mount Katmai, as previously thought, but from a new vent at Novarupta. The eruption removed so much molten rock (magma) from beneath Mount Katmai, however, that a cubic mile of Katmai's summit collapsed to form a 2-mile-wide volcanic depression, called a caldera, which now holds a lake 800 feet deep. Nearby Trident Volcano issued several lava flows (red) and small ash clouds during the decade beginning in 1953. There is no historical record of eruptions at Mageik, Martin, and Griggs Volcanoes, but their vigorous sulfur-rich fumaroles (volcanic gas vents) suggest that they might erupt in the near future.

expedition discovered a newly formed lava dome they called "Novarupta" and huge flows of volcanic ash filling what they named the "Valley of Ten Thousand Smokes" for the numerous plumes of steam rising from the still-hot ground. Griggs' descriptions of these spectacular features helped persuade President Woodrow Wilson to create Katmai National Monument (now National Park) in 1918.

In the 1950's, volcanologists discovered that the 1912 eruption was actually from Novarupta, not Mount Katmai. Novarupta's eruption had removed so much molten rock (magma) from beneath Mount Katmai that it caused a cubic mile of Katmai's summit to collapse.

The chance of another Novarupta-scale eruption occurring in any given year is small, but such cataclysmic volcanic events are certain to happen again in Alaska. Within 500 miles of Anchorage, volcanologists have identified at least seven deposits of volcanic ash younger than 4,000 years that approach or exceed the volume of ash ejected by Novarupta in 1912 , including a thick layer of ash erupted from Hayes Volcano, only 90 miles northwest of Anchorage. Of the numerous volcanoes scattered across southern Alaska, at least 10 are capable of exploding in a 1912-scale eruption.

When volcanoes erupt explosively, highspeed flows of hot ash (pyroclastic flows) and landslides can devastate areas 10 or more miles away, and huge mudflows of volcanic ash and debris (lahars) can inundate valleys more than 50 miles downstream. Around island volcanoes, like Augustine in Cook Inlet, pyroclastic flows and landslides can generate giant ocean waves (tsunamis) that threaten

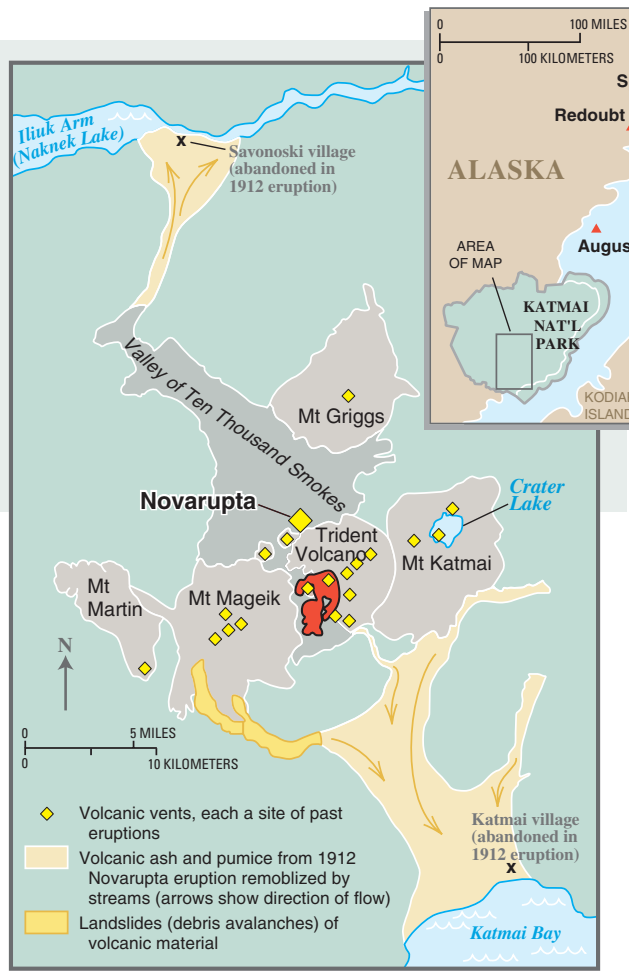

nearby coastal communities. Explosive eruptions can also produce large earthquakes. In 1912, when Novarupta exploded and Mount Katmai collapsed, 14 quakes of magnitude 6 to 7 rocked the region, and countless smaller shocks occurred. As with Novarupta, however, the greatest hazard posed by eruptions of most Alaskan volcanoes is airborne ash-even minor amounts of ash can cause the engines of jet aircraft to suddenly fail in flight, create health problems, close roads and airports, disrupt utilities, and contaminate water supplies for hundreds of miles downwind.

In 1912, Alaska was very sparsely populated, and there were few airplanes. Now, nearly three-quarters of a million people live in the State, and aircraft carrying more than 15,000 passengers and millions of dollars in cargo pass near Alaska's more than 40 historically active volcanoes each day.

The heavy ash fall produced by a Novaruptascale eruption occurring today in southern Alaska would bring the State's economy to a standstill and kill or injure hundreds. Clinics

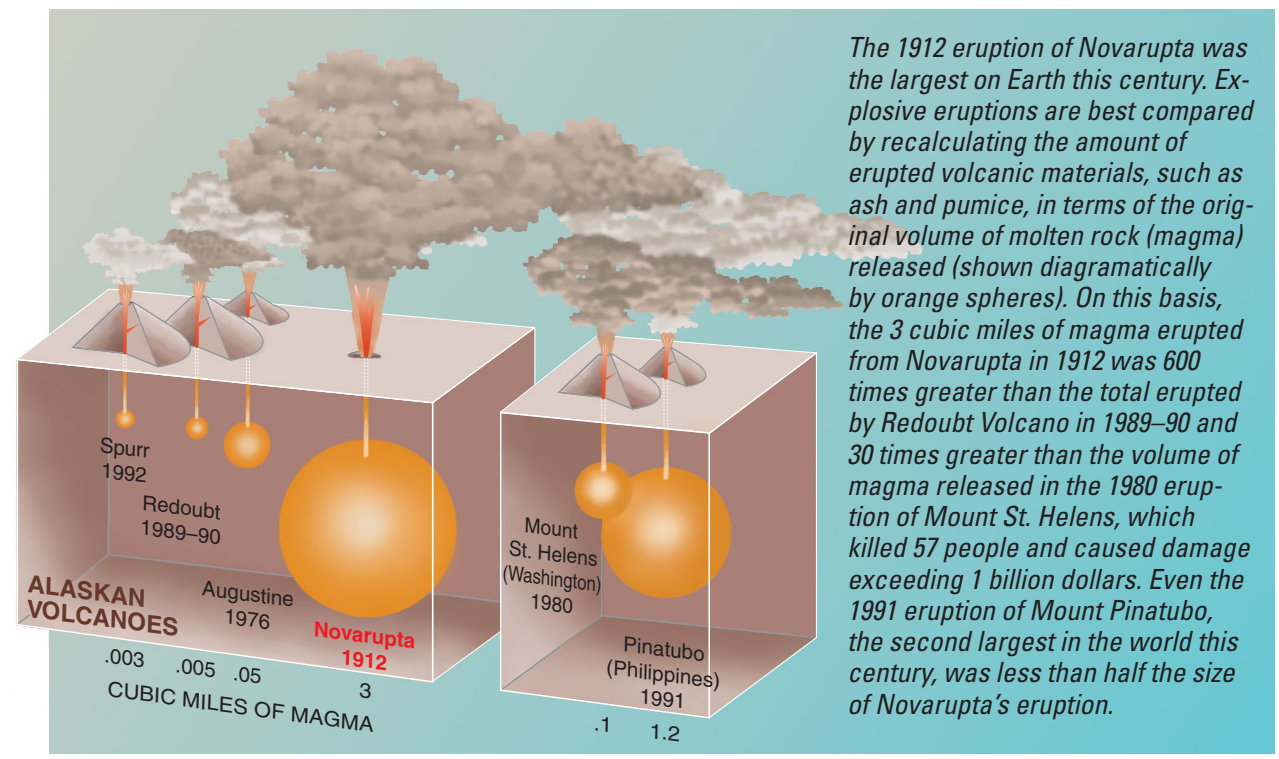

James W. Hendley II, and Peter H. Stauffer

Graphic design by

Susan Mayfield, Judy Fierstein, and Sara Boore

\section{COOPERATING ORGANIZATIONS}

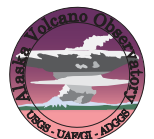

Alaska Division of Geological and Geophysical Surveys

Geophysical Institute, University of Alaska Fairbanks

Federal Aviation Administration National Geographic Society

National Park Service

National Weather Service

For more information contact:

Alaska Volcano Observatory (907) 786-7497

4200 University Drive

Anchorage, AK 99508

http://volcanoes.usgs.gov/

See also Volcanic Ash-Danger to Aircraft in the North Pacific (USGS Fact Sheet 030-97) 